\title{
ENERGY POTENTIAL OF SUGAR CANE BIOMASS IN BRAZIL
}

\author{
Tomaz Caetano Cannavam Rípoli*; Walter Francisco Molina Jr. ${ }^{1}$; Marco Lorenzzo Cunali Rípoli²,3 \\ ${ }^{1}$ Depto. de Engenharia Rural - USP/ESALQ, C.P. 9 - CEP: 13418-900 - Piracicaba, SP. \\ ${ }_{2}^{2}$ Pós-Graduando do Depto. de Engenharia Rural - USP/ESALQ. \\ ${ }^{3}$ Bolsista CNPq. \\ ${ }^{*}$ Corresponding author <tcripoli@carpa.ciagri.usp.br>
}

ABSTRACT: Brazil is a developing tropical country with abundant biomass resources. Sugar cane (Saccahrum spp.) is primarily produced to obtain sugar and alcohol. Presently sugar cane is burned before harvest. If the cane were not burned before harvest, the trash (tops and leaves) could be collected and burned to produce steam to generate electricity, or be converted into alcohol fuel and decrease the severe air pollution problems caused by sugar cane burning. Based upon logical assumptions and appropriate data, we estimate the number of people that could be served each year by this biomass if its energy was converted into electricity. From trash and bagasse, $7.0 \times 10^{6}$ and $5.5 \times 10^{6}$ people $\mathrm{y}^{-1}$ could be served, respectively.

Key words: sugar cane, biomass, energy

\section{POTENCIAL DA ENERGIA DE BIOMASSA DA CANA-DE-AÇÚCAR NO BRASIL}

\begin{abstract}
RESUMO: O Brasil é um país tropical em desenvolvimento com abundantes recursos de biomassa. A canade-açúcar é, primariamente, produzida para obtenção de açúcar e álcool. Atualmente os canaviais são queimados como prática de pré-colheita. Não se adotando tal prática, o palhiço (ponteiros, folhas verdes e palhas) podem ser recolhidos e queimados para produção de vapor para geração de eletricidade ou convertidos em álcool carburante, diminuindo a grande poluição atmosférica causada pela queima de canaviais. Este trabalho apresenta uma equação que permite estimar a quantidade de pessoas ano-1 que poderão ser servidas por essa biomassa, se convertida em eletricidade. Do palhiço e do bagaço, $7.0 \times 10^{6}$ e $5.5 \times 10^{6}$ pessoas ano ${ }^{-1}$ poderão ser servidas, respectivamente.
\end{abstract}

Palavras-chave: cana-de-açúcar, biomassa, energia

\section{INTRODUCTION}

One way to measure the development of a country is to examine its energy consumption "per capita". There is a strong dependency between development and available energy. TABLE 1 shows the energy consumption in four countries of different economic development.

In tropical countries like Brazil, that have abundant biomass resources, the primary goal in energy policy must be twofold: 1) biomass energy production and 2) environmental pollution control. Until now, most of the cane area in Brazil is burned before harvest. The pre-harvest burning removes approximately $80 \%$ of the trash (the tops, green leaves and dry leaves, or straw); it kills bees, snakes, and scorpions; it decreases accidents with knives and machetes; all of which increases the harvesting capacity for both hand labor and machines.

TABLE 1 - Energy consumption "per capita" in some countries (FAO, 1989 cited by Ripoli, 1991).

\begin{tabular}{lcrcc}
\hline Countries & Crude oil & Electricity & Coal & Natural gas \\
\hline & barrels & \multicolumn{1}{c}{ kWh } & metric ton & $\mathrm{m}^{3}$ \\
U.S.A. & 19.2 & 11,139 & 3.1 & 2,047 \\
Australia & 11.0 & 8,224 & 5.3 & 983 \\
Brazil & 3.0 & 1,519 & 0.1 & 19 \\
India & 0.4 & 272 & 0.2 & 80 \\
\hline
\end{tabular}

Because this pre-harvest burning causes environmental problems, there are Federal and State laws today that try to control this practice. Stopping the preharvest burning makes it possible to use the trash to produce steam and electricity by the sugar mills and distilleries, improving the amount of this kind of energy in the country's energy matrix.

One of the greatest problems in the harvesting of green (unburned) cane is the opposition of the Labor Unions. At this moment, the unions have good reason for not wanting to cut green cane - the harvest capacity of green cane decreases by $80 \%$, and the workers are paid in tons cut per day.

There will also be increased labor hazards. In green cane it is difficult to see where the stalks are, and where the ground is, raising the risks of cutting hands and fingers with the knife. It is possible that bees, snakes, spiders, and scorpions attack the laborers more frequently. And, the edges of green sugar cane leaves have thousands of microscopic prickles that can hurt the eyes, faces and arms of the laborers.

The solution to these problems will be to develop new safety equipment and to increase the payment for each ton of stalk cut by laborers by four or five times. More mechanization is another solution.

The problems with mechanization are more technical. First, most of the combine machines are designed to harvest burned cane. When used to harvest green cane they perform 
poorly, resulting in low material capacities $\left(\mathrm{t}^{-1}\right)$, high trash with the harvested stalks, and high losses of stalks ( $\left.\mathrm{t} \mathrm{ha}^{-1}\right)$. Second, today's mechanical cane loaders and conventional bailers do not perform well. It will be necessary to modify these machines in order that they load trash efficiently.

On the other hand, even with the above problems, we note that sugar cane bagasse already is used partially to produce electricity and rice hulls could also be used for producing electricity for small communities.

This paper presents the potential amount of electricity that could be produced from the bagasse and the trash of the sugar cane as compared with that from rice hulls in Brazil.

The utilization of biomass has some advantages as well as some problems, as is shown in Lanças (1984): advantages 1) an abundant resource, 2) renewable and available in several forms and several use varieties, 3) decentralized production with regional resources and 4) reduction of environmental pollution in relation to the use of fossil fuels. The problems are 1) large areas of any crop can cause ecological imbalance, 2) the low amount of energy for unit of weight, 3) it is barely viable when the price of petroleum is high, 4) it presents storage and transport problems and 5) it needs a pre-drying system to be more efficient.

The economical importance of the sugar cane agriindustry in Brazil shown by Agrianual (1996) in the 199697 season: sugar cane area, $4.6 \times 10^{6}$ ha, sugar cane stalks crushed/year: $307.5 \times 10^{6} \mathrm{t}$, sugar production: $7.2 \mathrm{x}$ $10^{6} \mathrm{t}$, alcohol production: $12.3 \times 10^{6} \mathrm{~m}^{3}$ by 327 sugar mills and distilleries. In South and East regions alone, the crop area is $2.73 \times 10^{6}$ ha. Ripoli (1998) shows that $1.2 \times 10^{6}$ people are working in that agri-industry, in Brazil.

Sugar cane has a life cycle of 12 or 18 months and yields a range of $50-150 \mathrm{t} \mathrm{ha}^{-1}$. The country's average is $70 \mathrm{t} \mathrm{ha}^{-1}$. The sugar cane area, $4.6 \times 10^{6} \mathrm{ha}$, is the fourth largest crop area in Brazil, following (in ha) corn $13.8 \times 10^{6}$; soybean $10.7 \times 10^{6}$; and beans: $5.3 \times 10^{6}$, Agrianual (1996).

In Brazil there are two harvesting systems in practice: hand labor and combine machines (Figure 1). In burned cane, workers can cut by hand 5-8 $\mathrm{t} \mathrm{d}^{-1}$ (Ripoli \& Molina Jr., 1991); the machines can cut 25-55 t d (Ripoli \& Mialhe, 1980). In green cane that is not burned, the harvesting capacity of a hand laborer decreases fivefold while that of a machine decreases only slightly to 25$45 \mathrm{t} \mathrm{d}^{-1}$, but increases the average amount of trash with the stalks harvested to $10 \%$ (Ripoli, 1998).

Burning the cane, however, brings several environmental problems. These include increased air pollution; the possibility of losing control of the fire in the fields; increased difficulty of using biological pest control; and occasional interruptions in high voltage lines when they are in the vicinity of the sugar cane fields. Additionaly, if burning causes temperatures to reach $980^{\circ} \mathrm{C}$, sucrose exudes from the stalks and is lost. Moreover, in such cases, the harvested stalks are contaminated with soil because the soil sticks to the exuded sucrose (Ripoli et al., 1990). Molina Jr (1991) determined that the trash index for sugar cane is $25 \%$. In other words, one quarter of all aerial vegetal mass of sugar cane is tops, leaves and straw.
The practice of burning (Figure 2) before harvesting occurs during the entire harvest season (May to November in the South and East regions, and September to February in the Northeast) causes severe environmental problems. Burning kills microorganisms in the topsoil, it burns the trash that could be used to improve soil conditions (trash is a good source of organic matter and nitrogen), it increases the ozone level in the lower atmosphere (in the State of Sao Paulo normal levels are 20 to $40 \mathrm{ppb}$; in industrial areas levels are $50 \mathrm{ppb}$ and in sugar cane areas during the harvest season levels are $80 \mathrm{ppb}$ ) and it increases the carbon monoxide levels in the atmosphere. Normal levels of ozone are $100 \mathrm{ppb}$, while those during the harvest season reach 600 ppb (INPE, 1989).

Considering the economics and energy balance for using the harvest trash from sugar cane fields, Ripoli (1991) showed the advantages of not burning the cane before harvesting and using the trash in sugar mills and/ or distilleries to produce steam for generating electricity. By not burning, he found that 1.28 equivalent barrels of oil was derived from each ton of trash.

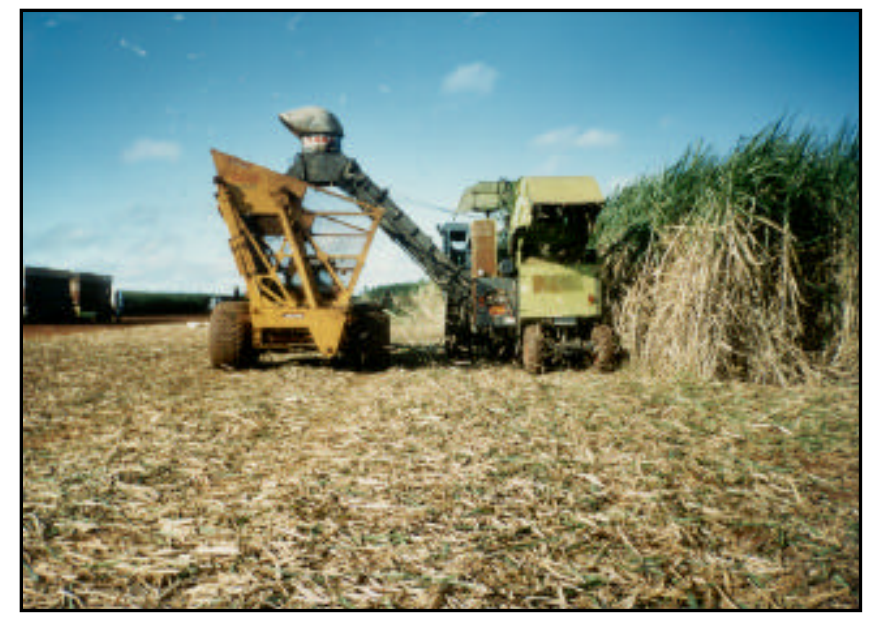

Figure 1 - Haversting in sugar cane area with no pre-burn. Notice the amount of trash in the ground after the harversting operation.

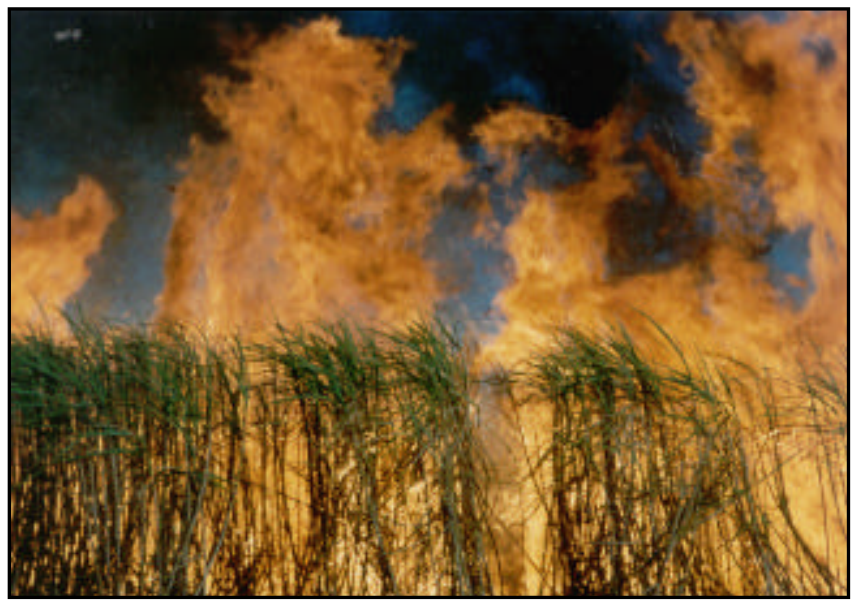

Figure 2 - The pre-harvesting burn in sugar cane field to eliminate most of the trash. 
In Brazil more than $90 \%$ of all electrical energy comes from hydroelectric sources. But, at the end of 1992, the State of Sao Paulo passed a law permitting the sugar mills and/or distilleries to sell the excess electrical energy they produced back to the State. This electricity comes from burning the sugar cane trash and bagasse (sugar cane fiber stalk after crushing). Until now, only five sugar mills in Sao Paulo State take advantage of the law (Ripoli, 1998).

In terms of energy consumption, the sugar mills and the alcohol distilleries in Brazil are sustainable because they burn the bagasse in boilers to produce steam. The new proposal is to use the excess bagasse not used for their own consumption, plus the sugar cane trash, to produce electric energy to be utilized in the commercial State or private electric system. This consumption will be a great advantage for the State of Sao Paulo (the most industrialized state of Brazil) because it now has a deficit of electric energy, and has to buy electrical energy from other States (Ripoli, 1998). Owing to the steep slopes of fields, Ripoli estimates that machines could harvest only $40 \%$ of the entire sugar cane area in Brazil. In the South and East regions, machine harvest could reach $50 \%$ of the total area. Several authors are studying sources of biomass energy. TABLES 2 and 3 show some examples of the gross heat and net useful heat of some biomass materials.

Ripoli (1991) studied two important sugar cane varieties used in Brazil and obtained the results shown in TABLE 4. Ripoli (1997) studied five other different varieties and the results were almost the same as shown in TABLE 4.

Ripoli \& Molina Jr (1991) made an estimate of how much energy is contained in one hectare of sugar cane. The result is equivalent to $280,730 \mathrm{MJ}$, distributed as follows: $24 \%$ in ethanol production, $37 \%$ in the actual use of the bagasse burned in the sugar mill and/or distillery boilers, and $39 \%$ in the trash (tops, green and dry leaves).

Copersucar (1989) showed $0.26 \mathrm{t}$ of bagasse $(50 \%$ humidity) is obtained per ton of sugar cane stalks crushed in sugar mills and/or alcohol distilleries. Today, the sugar mills use about $90 \%$ of the bagasse produced for their own consumption, but this consumption could be reduced to $70 \%$ if the steam system became more efficient (Copersucar ${ }^{1}$ ). Correa (1992) showed Brazil produces 59 million $\mathrm{t} \mathrm{y}^{-1}$ of bagasse (with $50 \%$ humidity).
TABLE 2 - Gross heat combustion from some biomass materials.

\begin{tabular}{lcl}
\hline Material & Gross heat & Authors \\
\hline & $\mathrm{kJ} \mathrm{kg} 1$ & \\
$\begin{array}{l}\text { Eucalyptus } \\
\text { tereticornis }\end{array}$ & 34,518 & Brito (1986) \\
$\begin{array}{l}\text { Pinus strobus } \\
\text { pine cone }\end{array}$ & 22,118 & Sunmer et al. (1983) \\
grape fruit pulp & 20,381 & \\
peach pulp & 19,381 & \\
sugar cane straw & 19,284 & \\
grape fruit & 18,870 & Ripoli et al. (1991) \\
cereal straw & 18,682 & Sunmer et al. (1983) \\
sugar cane green & 18,602 & Atchison (1977) \\
leaves & 18,439 & Ripoli et al. (1991) \\
sugar cane & 18,322 & \\
bagasse & 18,138 & \\
sugar cane tops &
\end{tabular}

TABLE 3 - Net (useful) heat of some materials.

\begin{tabular}{|c|c|c|}
\hline Materials & Net heat & Authors \\
\hline & $\mathrm{kJ} \mathrm{kg}^{-1}$ & \\
\hline gasoline & 43,943 & Goldenberg (1979) \\
\hline charcoal & 28,450 & \\
\hline alcohol anhydrous & 26,784 & \\
\hline alcohol hydrated & 19,670 & \\
\hline wood* & 23,336 & Brito (1986) \\
\hline \multicolumn{3}{|l|}{ sugar cane } \\
\hline straw* & 15,074 & Ripoli (1991) \\
\hline $\begin{array}{l}\text { bagasse, } 49 \% \\
\text { moisture* }\end{array}$ & 8,638 & \\
\hline $\begin{array}{l}\text { bagasse, } 50 \% \\
\text { moisture* }\end{array}$ & 7,868 & Maranhão (1983) \\
\hline green leaves* & 4,930 & \\
\hline tops* & 3,327 & \\
\hline trash & 13,551 & Ripoli (1998) \\
\hline
\end{tabular}

* Obtained using the equation of Doat (1977): $\mathrm{PC}=\mathrm{PCl}[(100-\mathrm{E}) /$ $100]-6 \mathrm{H}$, where $\mathrm{PC}\left(\mathrm{kcal} \mathrm{kg}^{-1}\right)$ is the net (useful) heat at $\mathrm{E}$ material moisture, $\mathrm{PCl}\left(\mathrm{kcal} \mathrm{kg}^{-1}\right)$ the inferior heat of the material, $\mathrm{E}(\%)$ the moisture in the material and $\mathrm{H}$ the quantity of hydrogen in the material.

TABLE 4 - Some characteristics of SP71-1406 and NA56-79 sugar cane varieties (Ripoli, 1991).

\begin{tabular}{|c|c|c|c|c|c|c|c|c|}
\hline \multirow[t]{2}{*}{ varieties } & \multicolumn{5}{|c|}{ SP71-1406 } & \multicolumn{3}{|c|}{ NA56-79 } \\
\hline & Humidity & c.v. ${ }^{*}$ & Yield & c.v. & Humidity & c.v. & Yield & C.v. \\
\hline & $\%$ & & $\mathrm{t} \mathrm{ha}^{-1}$ & & $\%$ & & $\mathrm{t} \mathrm{ha}^{-1}$ & \\
\hline stalks & 81.67 & 2.85 & 73.44 & 1.83 & 81.89 & 8.79 & 67.21 & 2.06 \\
\hline tops & 79.18 & 0.22 & 12.01 & 9.16 & 74.13 & 10.94 & 4.84 & 3.64 \\
\hline green leaves & 70.02 & 0.95 & 9.66 & 2.93 & 63.84 & 7.89 & 5.26 & 4.96 \\
\hline dry leaves & 12.94 & 3.83 & 10.11 & 4.96 & 8.23 & 3.00 & 9.44 & 13.90 \\
\hline pondered trash & & & 31.85 & & & & 19.52 & \\
\hline
\end{tabular}

${ }^{*}$ coefficient of variation 
In Brazil the average rice yield is $2.6 \mathrm{t} \mathrm{ha}^{-1}$ with $21 \%$ trash (hulls). The average hull humidity is $10 \%$ and the net heat is $15,401 \mathrm{MJ} \mathrm{t}^{-1}$ (Dario, 1995). The rice crop area in Brazil is 3,880,900 ha with an annual production of $10,077,200 \mathrm{t}$. In the South region, $1,079,000$ ha yields $5,150,900 \mathrm{t}$.

\section{METHOD}

The analysis of the energetic potentials of sugar cane and rice biomass is based upon a simple budget of mass and its equivalent energy relative to known national crop production estimates and the daily average consumption of energy per person in Brazil. The amount of trash $Q t\left(t^{~ h a-1}\right)$ in a field after harvesting is

$$
Q t=\operatorname{Tr}-\operatorname{tr}
$$

where $\operatorname{Tr}\left(\mathrm{t} \mathrm{ha}^{-1}\right)$ is the total amount of trash in the field before harvesting and $\operatorname{tr}\left(\mathrm{t} \mathrm{ha}^{-1}\right)$ is the total amount of trash that goes with the harvested material. The amount of material not harvested (i.e., lost) $\mathrm{Pe}\left(\mathrm{t} \mathrm{ha}^{-1}\right)$ is

$$
P e=0.01 p \cdot P
$$

where $p(\%)$ is the amount of material not harvested (lost) and $P\left(\mathrm{t} \mathrm{ha}^{-1}\right)$ is the amount of harvestable material in the field before harvesting. If $i(\%)$ is the amount of trash in the material harvestedand $\mathrm{Pa}\left(\mathrm{t} \mathrm{ha}^{-1}\right)$ is the amount of harvested material (sugar cane or rice + trash), then

$$
\text { tr }=0.01 i \cdot P a
$$

Recognizing that

$$
P=(P a-t r)+P e
$$

and substituting [2] and [3] into [4], we have

$$
P=P a \frac{(1-0.01 i)}{(1-0.01 p)} \text {. }
$$

Ripoli (1991) defined the Trash Index $\beta$ as

$$
\beta=\frac{T r}{P}
$$

Replacing [5] in [6] we have

$$
\operatorname{Tr}=\beta P a \frac{(1-0.01 i)}{(1-0.01 p)}
$$

Hence, after replacing [3] and [7] in [1],

$$
Q t=P a\left[\frac{\beta(1-0.01 i)}{(1-0.01 p)}-0.01 i\right]
$$

We now consider the amount of trash energy $\alpha(\%)$ to be used to produce electric energy and the area harvested per year $A c$ (ha $\left.y^{-1}\right)$. With the net heat of the trash at humidity $u$ being $P u\left(\mathrm{MJ} \mathrm{t}^{-1}\right)$, the available energy per year $E e\left(\mathrm{MJ}^{-1}\right)$ is

$$
E e=P u \cdot \alpha \cdot A c \cdot Q t
$$

Considering that $1 \mathrm{kWh}$ equals $3.6 \mathrm{MJ}$ and that the conversion process from trash to electric energy has an efficiency $E f(\%)$, the net transformed energy $\mathrm{Qa}\left(\mathrm{MJ} \mathrm{y}^{-1}\right)$ is

$$
Q a=\frac{E e \cdot E f}{3.6}
$$

Assuming the daily average energy consumption per person is $C d\left(\mathrm{kWh} \mathrm{d}^{-1}\right)$, the number of people $P d$ served during a year will be

$$
P d=\frac{Q a}{365 C d}
$$

Substituting [10] into [11] yields

$$
P d=\frac{E e \cdot E f}{1314 C d}
$$

Replacing [9] in [12] gives the estimate of the number of persons that could be served by electrical energy generated from the trash biomass. Hence,

$$
P d=\frac{P u \cdot \alpha \cdot A C \cdot Q t \cdot E f}{1314 C d}
$$

Equation [10] can also be used to estimate the amount of electrical energy that can be obtained from bagasse. For such calculations, the variables $i$ and $p$ are null (at equation 8) and the variable $\beta$ is the amount (\%) of bagasse resulting from all the material crushed during the harvesting season.

\section{RESULTS AND DISCUSSION}

Based on information published in the literature, the data cited in the Appendix were used to estimate the energy potential in sugar cane trash, sugar cane bagasse and, for comparison, in rice hulls shown in TABLE 5.

Around 12.5 million people can be served by trash and bagasse energy, which equals more than the population of Portugal (10 million people). These numbers show that the country is losing a very important renewable energy resource, basically in the sugar cane crop. It is important for a country like Brazil, which has energy problems, to make better use of this biomass resource. Similar situations are occurring in all sugar cane producing countries in the world (more then fifty), the largest being Brazil, Cuba, Australia, South Africa, Peru, Mexico, and India. Like Brazil, Cuba, the United States, and Australia have already started no burn harvest programs. In the last 8 years Cuba and Brazil have developed research programs for using the sugar cane trash and bagasse to produce electricity.

The use of rice hulls to produce electrical energy at this moment is more difficult because this trash is not concentrated in big industries. There are hundreds of small plants that process the gross rice. Transporting the hulls to one main generation plant remains a serious limitation.

\section{CONCLUSIONS}

Sugar cane trash and bagasse have great potential for being used to improve and to diversify the energy matrix of the South and East regions of Brazil. On the other hand, in terms of energy, rice hulls could only be used to make rice plant processors sustainable, but not to be sold to distributor companies.

\footnotetext{
${ }^{1}$ Personal information
} 
TABLE 5 - Number of people Qt served energy derived from sugar cane trash, sugar cane bagasse and rice hulls using equations [8] and [13].

\begin{tabular}{lccccc}
\hline Material & $P u$ & $\alpha$ & $A c$ & $Q t$ & $P d$ \\
\hline & MJ t$^{-1}$ & $\%$ & ha y $^{-1}$ & t ha $^{-1}$ & people $y^{-1}$ \\
$\begin{array}{l}\text { sugar cane } \\
\text { trash }\end{array}$ & 13,551 & 50 & $1.371 \times 10^{6}$ & 16.00 & $7.00 \times 10^{6}$ \\
$\begin{array}{l}\text { sugar cane } \\
\text { bagasse }\end{array}$ & 7,868 & 30 & $2.73 \times 10^{6}$ & 18.20 & $5.55 \times 10^{6}$ \\
rice hulls & 15,401 & 80 & $1.798 \times 10^{6}$ & 0.257 & $0.26 \times 10^{6}$ \\
\hline
\end{tabular}

\section{REFERENCES}

ATCHISON, J.E. Making the bagasse available for pulp, paper, board, fiber board, particle board and others industrial products at what price equivalent fuel values of bagasse and other fibrous row materials as compared to fossil fuels. In: CONGRESS OF ISSCT, 16., São Paulo, 1977. Proceedings. São Paulo, 1977. v.2, p.3129-3144.

BRITO, S.S. Energia de biomassa: uma alternativa para os trópicos. In: CONGRESO PANAMERICANO DE ENERGIA, 3., Guatemala, 1986. Anais. São Paulo: CONFEA,CREA, 1986. 20p.

COOPERATIVA CENTRAL DOS PRODUTORES DE AÇÚCAR DO ESTADO DE SÃO PAULO. Pró-álcool: fundamentos e perspectivas. São Paulo: COPERSUCAR, 1989. 121p.

CORREA, A.M.M. Uso da biomassa como fonte de energia. Jaboticabal: SBEA, 1992. 8p. (Boletim Informativo)

DARIO, G.J.A. Informações básicas para a cultura do arroz. Piracicaba: ESALQ, 1995. 28p.

DOAT, A. Le pouvoir calorifique des bois tropical. Bois et Forets des Tropiques, v.172, p.33-48, 1977.

FNP CONSULTORIA E COMÉRCIO. Agrianual 1997. São Paulo, 1996. 435p.

FURLANI NETO, V. L. Colhedora de cana-de-açúcar (Saccharum spp.): avaliação em canaviais com e sem queima prévia. Piracicaba, 1995. 110p. Tese (Doutorado) -Escola Superior de Agricultura "Luiz de Queiroz", Universidade de São Paulo.

GOLDENBERG, J. Biomassa como fonte de energia. Energia, n.1, p.21-22, 1979.

INPE-Instituto Nacional de Pesquisas Espaciais mede efeitos das queimadas em São Paulo. Jornal de Piracicaba, 26 set. 1989. p.25.

HILER, E. A.; STOUT, B.A. Biomass energy-a monografh. College Station: Texas A\&M University Press, Texas Engineering Experiment Station, 1985. 313p.

LANCAS, K.P. A evolução das alternativas energéticas com a crise do petróleo e a projeção da biomassa. Botucatu: UNESP, 1984. 34p.

MOLINA JR., W.F. Enfardamento de resíduo de colheita de canade-açúcar (Saccharum spp.): avaliação dos desempenhos operacional e econômico. Piracicaba, 1991. 128p. Dissertação (Mestrado) - Escola Superior de Agricultura Luiz de Queiroz, Universidade de São Paulo.

MARANHÃO, L.E. Secagem do babaço: avaliação do bagaço da cana-de-açúcar. Revista SOPRAL, p.40-48, 1983.

RIPOLI, T.C.C. Utilização do material remanescente da colheita da cana-de- açúcar (Saccharum spp.): equacionamento dos balanços energético e econômico. Piracicaba, 1991. 150p. Tese (Livre Docência) - Escola Superior de Agricultura Luiz de Queiroz, Universidade de São Paulo.
RIPOLI, T.C.; MIALHE, L.G.; BRITO, J.O. Queima de canavial: o desperdício não mais admissível! Álcool \& Açúcar, n.54, p.18-23, 1990.

RIPOLI, T.C.; MOLINA JR., W.F. Cultura canavieira: um desperdício energético. Maquinaria Agrícola, n.1, p.2-3, 1991.

RIPOLI, T.C.; L.G. MIALHE. Evaluation of some performance parameters of three combine harvesters of sugar cane (Saccharum spp.). In: CONGRESS OF INTERNATIONAL SOCIETY OF SUGAR CANE TECHNOLOGISTS, 17. Manilla, 1980. Proceedings. Manilla:ISSCT, 1980. p.1036-1057.

RIPOLI, T.C. Biomassa da cana-de-açúcar: perspectivas. In: Cana crua; experiência acumulada. workshop 4-Corte manual e mecânico, carregamento e transporte. UNESP- STAB. Novembro, 1998.

RIPOLI, T.C. Substituição do bagaço pela palha da cana-deaçúcar (Saccharum spp) como combustível para fornalhas de usinas e destilarias. Piracicaba: ESALQ; CNPq, 1997. 222 p. (Relatório Anual)

RIPOLI, M.L.C. Determinação de perdas de açúcares totais, por exsudação, decorrentes da queima de canavial Piracicaba: ESALQ; CNPq, 1998. 86p. (Relatório Parcial de Atividades)

SUMNER, H.R.; SUMNER, P.E.; HAMMOND, W.C.; MONROE, G.E. Indirect fire biomass furnace and bomb calorimeter determinations. Transactions of the ASAE, v.15, p.280-285, 1983.

APPENDIX - Data used to estimate the energy potential in sugar cane trash, sugar cane bagasse and rice hulls

Pu $\left(\mathrm{MJ} \mathrm{t}^{-1}\right)=13.551$ (for sugar cane trash), Ripoli (1998)

$=7.868$ (for sugar cane bagasse), Maranhão (1983)

$=15.401$ (for rice hulls), Dario (1995)

$\alpha(\%)=50$ (for sugar cane trash), Ripoli (1998)

$=30$ (for sugar cane bagasse), Copersucar ${ }^{4}$

$=80$ (for rice hulls), estimate for the South and West regions, only.

Ac $\left(\right.$ ha $\left.y^{-1}\right)=1,365,000$ (for sugar cane trash), Agrianual (1996), considering only $50 \%$ of total crop area where the mechanical harvesting is possible

$=2,730,000$ (for sugar cane bagasse), Copersucar (1989), Copersucar ${ }^{4}$ South and East regions, only. $=1,792,500$ (for rice hulls), Agrianual (1996) South and West regions, only.

$P a\left(\right.$ h ha $\left.^{-1}\right)=70$ (for sugar cane), Agrianual (1996)

$=2.6$ (for rice), Dario (1995).

$\beta(\%)=32$ ( sugar cane), Molina Jr (1991).

$=21$ (rice hulls), Dario (1995) .

bagasse $\left(\mathrm{t} \mathrm{ha}^{-1}\right)=18.2$ (assuming $0.26 \mathrm{t}$ of bagasse $\left(\mathrm{t}\right.$ of cane) ${ }^{-1}$ and $70 \mathrm{t}$ (ha of cane) ${ }^{-1}$, Agrianual (1996) Copersucar $^{4}$

$i(\%)=8.1$ (for sugar cane), Furlani Neto (1995), $10 \%$ for the rice. $p(\%)=5$ (for sugar cane), Ripoli (1998), $5 \%$ for the rice.

$E f(\%)=8.7$ (estimate for small power plant), Hiler \& Stout (1985). $C d\left(\mathrm{kWh} \mathrm{d}^{-1}\right)=1.4$ (personal low income consumption) $\mathrm{CPFL}^{2}$

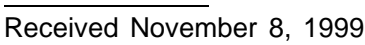

2São Paulo State Electricity Company information. 